\title{
Communication Pattern of Parents in Nuclear Families
}

\author{
Nofha Rina \\ Communication and Business Faculty \\ Telkom University \\ Bandung, Indonesia \\ nofharina80@gmail.com
}

\begin{abstract}
This research was conducted to find out the role of family communication in tackling juvenile delinquency in Bandung City. The focus are: teenagers motives in doing delinquency action, parenting patterns which applied by parents to adolescents, obstacles encountered by parents and adolescents in family communication process. This research used qualitative research method with phenomenological perspective. The subject of this study was adolescents (17-19 years old) and parents of the adolescents who live nuclear family, the object of this study was the pattern of family communication in Kelurahan Pasirbiru. The results showed that the phenomenon of juvenile delinquency in Kelurahan Pasirbiru occurred due to the lack of family communication intensity, the control and the limited guidance of parents on the behavior of adolescents. Democratic parenting (free but responsible) is an effective pattern in minimizing and preventing juvenile delinquency.
\end{abstract}

Keywords-communication; pattern; nuclear; family

\section{INTRODUCTION}

Communication is core of all social relationships in family communication activities. Not knowing time of day or night, morning or afternoon, in the community, at school and others. What's certain if someone make social contact then in it will happen communication.

Wursanto in Djamarah says that communication can take place anytime, anywhere, anytime, by anyone and with anyone [1]. Communication has made relation with the surrounding community groups. The first group experienced by a newborn individual is the family. The relationship an individual does with his mother, father, and other family members. Establishing a good communication relationship is so important in the framework of personality development and the development of a person's interaction quality.

In adolescence, a person will experience various changes about himself, both physical and psychological development. Teenagers are generally very vulnerable to the influence of their environment. Because at this time many teenagers experience various problems of psychological psyche, which unwittingly adolescents will experience the process of identity seeking. This is often called a "crisis of identity" so that teenagers are prone to fall into the various forms of social deviation, or more commonly known as juvenile delinquency
Juvenile delinquency is a "black circle" that never breaks. Connect from time to time, from year to year more complicated. The trigger factors, among others, are the failure of adolescence through the transition period, from childhood to adulthood, and also because of weak self-defense against the influence of the outside world is not good.

Bandung is one of the capital city of West Java Province where one of the sub-districts in Bandung is Cibiru sub-district. Cibiru Sub-district is one of the sub-districts that still experience expansion of residential area because it has the potential of fertile land and wide. So that Cibiru district belonging to East Bandung area become favorite area in residential development and phenomenon that stand out here is in the form of juvenile delinquency which often happened in nuclear family and done from generation to generation.

Based on the observation in the field that the action of fighter brawl of high school students and among junior high school students occurred at various location points in Cibiru area within one decade. This problem is certainly very disturbing to many parties and therefore, researchers feel interested and challenged to conduct a study in District Cibiru. After going through various considerations and observations, the researchers decided Kelurahan Pasirbiru, District Cibiru as a point of the right location for this study.

In Kelurahan Pasirbiru, the phenomenon of juvenile delinquency often occurs. Some forms of juvenile delinquency in this village include: cigarettes, ditching schools, motor racing (wild), theft, gambling and brawl. Based on information from residents around the study site, this problem has existed from several generations before and even continues to "thrives" from generation to generation.

Talking about teenage acquaintances is closely related to family factors, which involves the pattern of students and the intensity of communication (parents - children) in the family. Many parents apply the concept or method of how to educate adolescents whose barometer is only ambitious that the child should be in accordance with what the parents want and expect. Not a concept of how the child can understand, understand what a teenager's responsibilities are at his age, in order to become a child with self-confidence and responsibility.

Family factors are very influential on the emergence of juvenile delinquency itself. Lack of support, attention, improper or ineffective discipline such as the exercise of 
discipline that is too restrictive or authoritarian or too free or permissive, especially lack of affection, are the factors that can trigger the onset of juvenile delinquency.

At present the problem of unpreparedness of parents in fostering children is often regarded as the trigger of social problems and delinquency in children, because parents are considered less able to give special attention to the child. The interaction and communication in the family (parent - child) is less dynamically created. For families who are able to hold good communication to the child will certainly give attention and affection to children, on the other hand for parents who are super busy and ignorant of child development is rarely the process of interaction or communication in the family. Consequently, a child raised in an uncommunicative parent is likely to seek attention to other environments, such as in a school environment or a playground environment.

Disputes and stress experienced by the family are also closely related to juvenile delinquency. Juvenile delinquency has become a complex problem occurring in various cities in Indonesia. Not only in big cities, this problem has also become a "classic" problem in Pasirbiru region. Of course all parties (no exception) feel restless and hope that problems in this area can be addressed, therefore the authors conduct a research with the intent and purpose for this problem can be overcome.

Based on the description on the background, then the formulation of the problem in this study is: What is the communication pattern of parents in nuclear family?

\section{A. Family Communication Pattern}

Communication of an activity that must occur in family life. Without communication, split the family life from the activities of dialogue, exchange ideas and so forth. Communication between parents (husband and wife) basically should be open. This is because husband and wife have been a unity. Open communication is expected to avoid misunderstanding. Within certain limits, the nature of openness in communication is also carried out with children, that is, when the children have been able to think well, the child has been able to consider well about the things he faces.

Listening sympathetically is indicated by: (a) Be sensitive to the feelings that accompany the message conveyed; (b) Listening intently; (c) Not interrupting the conversation or commenting in the middle; (d) Attention to the "world" of the speaker. The problem is the pattern of communication that often happens in family life. According to Djamarah, there are 3 communication patterns in the family such as StimulusResponse model, ABX model, and Interactional models [1].

\section{B. Stimulus-Response Model}

The communication pattern that usually occurs in the family is the stimulus-response model (S-R). This pattern shows communication as a process, a very simple 'reactionaction'. The S-R pattern assumes that verbal (oral-writing) words, nonverbal cues, pictures, and certain actions will stimulate others to respond in a certain way. Therefore, this process is considered as the exchange or transfer of information or ideas. This process can be reciprocal and has many effects, each effect can change the next communication action

\section{ABX Model}

The ABX model was proposed by Newcomb from the perspective of social psychology. Newcomb illustrates that a person (A) conveys information to someone else (B) about something (X). According to Mulyana, if $\mathrm{A}$ and $\mathrm{B}$ have a positive attitude toward each other and to $X$ (person, idea or thing) the relationship is symmetry [2]. In this context, Mulyana asserts that when $\mathrm{A}$ and $\mathrm{B}$ hate each other and one likes $\mathrm{X}$, while others do not, the relationship is also symmetry. However, if A and B like each other, but they disagree about $\mathrm{X}$ or if they hate each other, but agree on $\mathrm{X}$, then their relationship is not symmetry. In family relationships, the husband and wife often talk about their children, whether it is related to the attitudes and behaviors of children, the association of children, the issue of food clothing or food, or the issue of children's education. When the parents' conversation went on, the child was not involved in the conversation at all. As the object is discussed, the child is just waiting for the results and maybe implementing it to the extent of his ability.

\section{Interactional Models}

This interactional model is in contrast to the S-R. The S-R model assumes humans are passive, while the interactional model assumes humans are much more active. Here, communication is described as the formation of meaning, ie the interpretation of the message or behavior of others by the participants of communication. In the family, interaction occurs in various forms, and that initiates the interaction not necessarily from the parent to the child, but can also vice versa from child to parent, or from child to child. Everything is active, reflective and creative in the interaction. The family atmosphere is active and dynamic in the activities of communication, the dialogical atmosphere is more open, because the active delivery of certain messages not only from parents to children, but also from children to parents or from children to children.

\section{E. Youth and Juvenile Delinquency}

Adolescence is a period of transition between childhood and adulthood, which begins at the time of sexual maturity between the ages of 11 or 12 years up to 20 years, ie before the young adulthood [3].

According to Hurlock: Adolescence comes from the Latin word adolescence which means to grow or grow into adulthood. At the end of adolescence, his soul is not easily affected and was able to select and select. Teens also begin to learn to be responsible for themselves, their families, and the environment. Juvenile delinquency is an act that violates the norms, rules, or laws in society committed in adolescence or the transition of childhood into adulthood. According Kartini Kartono juvenile delinquency is a symptom of social pain in children and adolescents caused by a form of social neglect, so they develop a form of deviant behavior [4].

\section{F. Phenomenological Perspective}

In supporting the theory, researcher also complement the basis of this theory by using a phenomenological perspective 
approach (Alfred Schutz). According to Alfred Schutz, the main task of phenomenological analysis is to reconstruct the "real" world of human life in their own form [5].

Schutz's core idea is how to understand social action through interpretation. The process of interpretation can be used to clarify or examine the real meaning, so as to provide an implicit concept of sensitivity. Schutz places the human essence in a subjective experience, especially when taking action and taking an attitude toward the world of everyday life.

\section{RESEARCH METHOD}

The method used in this research is: qualitative method with phenomenology approach. Qualitative research is an approach that is also called investigative approach because researchers usually collect data by face to face face-to-face and interact with people in place of research [7]. As Deddy Mulyana confirmed in his book Qualitative Research Methodology, this research is to find individual subjective responses.

\section{RESULT AND DISCUSSION}

Teenagers in Kelurahan Pasirbiru do juvenile delinquency action against a variety of motives. If associated with the approach of phenomenological perspective from Schutz is the existence of motives that are oriented in the past ie the influence of friends, seeking attention (parent), driven by curiosity or want to try, want to be accepted in the social environment, and want to get the predicate slang in the eyes social friends; then the motive that is oriented to the present is, to seek pleasure, just to seek popularity, and look for the image (naughty) inherent; as well as future-oriented motives is to want a figure and his name continues to be remembered in the future.

From the research results obtained some kind of parenting applied by parents to adolescent children in Kelurahan Pasirbiru namely permissive, authoritarian, democratic and neglected parenting. Parenting to teenagers also trigger opportunities for juvenile delinquency. The nature and behavior of children is strongly influenced by the parenting pattern of both parents. Too pamper or look at their presence, can be bad for their personality later. Therefore, children who grow up and grow in false and negative patterns or supportive environments tend to have negative self-concepts such as juvenile delinquency, and a positive attitude of parents will cultivate positive concepts and thoughts and self-respect.

Parents who apply authoritarian parenting with the intention that children obey and respect the parents, it will make children want to do deviant behavior outside the home. Children assume that he is free and no one set him outdoors. In reality on the ground, there are some obstacles that parents and teenagers encounter in family communication activities. These obstacles include, parent's busyness, parent ego, children often out of the house, the impact of technological advances in the internet, games and obstacles that are situational like television shows.

Although informant parents are aware of their current state of affairs, they still have a hope that through this more effective and intensive family communication it can cope with the phenomenon of juvenile delinquency that has already occurred and prevent it from happening in the future. Building a good, intensive family communication pattern and building emotional closeness between parents and teenagers can minimize the happening of juvenile delinquency phenomenon.

\section{CONCLUSION}

Based on the result of the research, it can be concluded that the phenomenon of juvenile delinquency in Kelurahan Pasirbiru occurs because the lack of communication intensity of the family, then the control and guidance of parents to the behavior of adolescent children (concerning, agarma education and morality values) is very limited.

The results show that there are some motives behind the adolescent in Kelurahan Pasirbiru do juvenile delinquency, namely: friends, curiosity, the environment, want to be called slang and gentle, looking for parental attention, fun, seeking popularity, imagery, and want to be remembered.

The parenting pattern applied by the parent to the child (teenager) in the research location is the permissive parenting pattern (soft and spoiled), authoritarian parenting (hard and discipline), democratic parenting (free but responsible) and neglect (free and indifferent). Parenting above is a picture of the life of teenage informants in this study.

Based on the results of research can be concluded that the application of existing patterns in the location of research is still less effective in tackling and preventing the happening of juvenile delinquency. Family communication created between parents and children is interpersonal communication by using verbal messages that contain attention, affection, empathy and support, with the intensity of communication that focuses on the quality of the conversation or how deep the message is communicated, with the duration different conversations. This is quite influential on the development of the child's personality and impact on the possibility of the form of juvenile delinquency. Effective pattern in minimizing and preventing juvenile delinquency is a free (democratic) free pattern, but still taking into account the control and quality of communication that exists between parents, so that children can counteract things that can trigger the happening of juvenile delinquency.

The obstacles parents and teenagers encounter in the family communication process are: the parent's busyness causes the parent's time for the child to be limited due to the busyness of the parents, the child often out of the house causing the interaction between parent and adolescent to be very less, the impact of technology or the internet or game making the users of these services are addicted to the impact on family communication activities, parents' ego is that parents spend more time with their friends (usually in the form of arisan), neighbors, and other personal affairs and television shows also become a barrier in family communication activities, because it cannot be denied that sinetron shows often hypnotize women especially housewives.

\section{REFERENCES}

[1] Djamarah, Bahri, Syaiful, Pola Komunikasi Orang Tua dan Anak dalam Keluarga, Jakarta: PT. Rhineka Cipta, 2004. 
[2] Mulyana, Deddy, Ilmu Komunikasi, Pengantar. Bandung: PT Remaja Rosdakarya, 2000.

[3] Soetjiningsih, Tumbuh Kembang Remaja dan Permasalahanya, Jakarta: PT. Rhineka Cipta, 2004, hal.45

[4] Kartini, Kartono, Kenakalan Remaja, Jakarta: PT. Raja Grafindo Persada, 2003, hal. 6-7

[5] Schutz, Alfred, The Phenomenology of The Social world. London: Heinemann Educational Book, 1972
[6] McMillan, J. H., \& Schumacher, S, Research in Education: A Conceptual Introduction (5th ed.), New York: Longman, 2003

[7] Mulyana, Deddy, Metodologi Penelitian Kualitatif: Paradigma Baru Ilmu Komunikasi Dan Ilmu Sosial Lainnya. Bandung: PT Remaja Rosdakarya, 2011 